\title{
TAM receptor ligands in lupus: Protein $S$ but not Gas6 levels reflect disease activity in systemic lupus erythematosus
}

\author{
Chang-Hee Suh ${ }^{1,2}$, Brendan Hilliard', Sophia Li', Joan T Merrill³, Philip L Cohen ${ }^{1 *}$
}

\begin{abstract}
Introduction: The TAM (tyro 3, axl, mer) kinases are key regulators of innate immunity and are important in the phagocytosis of apoptotic cells. Gas 6 and protein $\mathbf{S}$ are ligands for these TAM kinases and bind to phosphatidyl serine residues exposed during apoptosis. In animal models, absence of TAM kinases is associated with lupus-like disease. To test whether human systemic lupus erythematosus (SLE) patients might have deficient levels of TAM ligands, we measured Gas 6 and protein S levels in SLE.

Methods: 107 SLE patients were recruited. Of these, 45 SLE patients were matched age, gender and ethnicity with normal controls (NC). Gas6 and free protein $S$ were measured with sandwich enzyme linked immunosorbent assays (ELISAs).
\end{abstract}

Results: Overall, the plasma concentrations of Gas6 and free protein S were not different between 45 SLE patients and $45 \mathrm{NC}$. In SLE patients, the levels of free protein $S$ were positively correlated with age $(r=0.2405, P=0.0126)$, however those of Gas 6 were not. There was no correlation between the concentrations of Gas 6 and free protein $S$ in individuals. Levels of free protein S were significantly lower in SLE patients with a history of serositis, neurologic disorder, hematologic disorder and immunologic disorder. Gas6 levels were elevated in patients with a history of neurologic disorder. The SLE patients with anti-Sm or anti-cardiolipin IgG showed lower free protein $S$ levels. Circulating free protein $S$ was positively correlated with complement component 3 (C3) $(r=0.3858, P<0.0001)$ and complement component 4 (C4) $(r=0.4275, P<0.0001)$. In the patients with active BILAG hematologic involvement, the levels of free protein $S$ were lower and those of Gas6 were higher.

Conclusions: In SLE, free protein S was decreased in patients with certain types of clinical history and disease activity. Levels of free protein S were strongly correlated with C3 and C4 levels. Gas6 levels in SLE patients differed little from levels in NC, but they were elevated in the small numbers of patients with a history of neurological disease. The correlation of decreased protein $S$ levels with lupus disease activity is consistent with a role for the TAM receptors in scavenging apoptotic cells and controlling inflammation. Protein $\mathrm{S}$ appears more important functionally in SLE patients than Gas6 in this regard.

\section{Introduction}

Systemic lupus erythematosus (SLE) is a chronic autoimmune disease with diverse presentations. Its pathogenesis remains elusive; however, multifactorial interactions among genetic and environmental factors may be involved $[1,2]$. SLE is characterized by dysregulation of the immune system that involves hyperactivity of

\footnotetext{
* Correspondence: philco@temple.edu

'Section of Rheumatology, Department of Medicine, Temple University

School of Medicine, 3322 North Broad Street, Room 205, Philadelphia, PA 19140, USA
}

$\mathrm{T}$ cells and B cells, production of pathogenic autoantibodies, and the formation of immune complexes, which can lead to multiorgan damage.

Certain nuclear and cytoplasmic autoantigens become clustered in the surface blebs of apoptotic cells [3]. Under normal circumstances, apoptotic cells are engulfed by macrophages in the early phase of cell death without inducing inflammation or the immune response. In SLE, however, the clearance of apoptotic cells by macrophages is impaired, which may allow apoptotic cells to serve as immunogens for the

\section{Biomed Central}


induction of autoreactive $\mathrm{T}$ and $\mathrm{B}$ cells and drive the production of autoantibodies [4].

The reasons for the defective clearance of apoptotic cells in SLE are not clear. The past decade has provided significant evidence that complement deficiencies, immunoglobulin (Ig) M deficiency, pentraxin deficiency and defects in macrophage handling may each contribute to defective clearance of apoptotic bodies [5-7]. Macrophages recognize apoptotic cells through an array of surface receptors. Among them, the tyro 3, axl, mer (TAM) kinases, especially the c-mer receptor tyrosine kinase, play an especially important role in the clearance of apoptotic cells $[8,9]$. Mice lacking c-mer have impaired clearance of apoptotic cells and develop progressive lupus-like autoimmunity [10]. The two ligands that bind to and activate c-mer are growth arrest-specific 6 (Gas6) and protein S, which in turn bind to phosphatidylserine residues exposed early in apoptosis on the surface of the apoptotic cell [11-14].

Gas6, a $75 \mathrm{kDa}$ multimodular vitamin K-dependent protein that has 46 to $48 \%$ amino acid identity to protein S, was discovered in the early $1990 \mathrm{~s}$ [15]. It contains an $\mathrm{N}$-terminal $\gamma$-carboxyglutamic acid (Gla) domain, interacting with phosphatidylserine containing membranes, followed by four epidermal growth factorlike domains and a large $\mathrm{C}$-terminal region homologous to the sex hormone binding globulin, can ligate TAM receptor tyrosine kinases [16]. Gas6 is expressed in many tissues, including capillary endothelial cells, vascular smooth muscle cells, and bone marrow cells. Unlike protein S, Gas6 is not expressed in the liver, and its concentration in plasma is 1,000 -fold lower than that of protein S [17].

Protein $\mathrm{S}$ has a critical function in regulating coagulation by serving as a cofactor for activated protein Cdependent proteolytic inactivation of factor $\mathrm{Va}$ and factor-VIIIa. Protein S circulates as approximately $40 \%$ free protein $\mathrm{S}$ and $60 \%$ as a complex with C4-binding protein; only free protein $\mathrm{S}$ is active as a cofactor for activated protein $\mathrm{C}$ and a ligand for the TAM receptor kinases. In the absence of free protein $S$, there is increased risk of thromboembolism [18].

It is reasonable to hypothesize that Gas6 and protein S might have important roles in the pathogenesis of SLE. Recently, plasma Gas6 was reported to be elevated in patients with severe sepsis, septic shock, and severe acute pancreatitis [19-21]. However, there are no reports about Gas6 levels in SLE. Low levels of protein S are reported in SLE, and could be contributing to the thrombotic propensity in certain SLE patients [22-24]. We have therefore compared Gas6 and free protein S concentrations in patients with SLE, examining their possible use as biomarkers of clinical phenotype and/or disease activity.

\section{Materials and methods Subjects}

Samples from 107 SLE patients, participating in the Oklahoma Cohort for Rheumatic Disease, were studied. All patients satisfied at least four of the 1982 revised American College of Rheumatology (ACR) criteria for SLE [25]. Forty-five of these SLE patients were matched by age, gender and ethnicity to healthy normal controls (NC) (Table 1). Heparinized plasma samples were collected and stored at $-70^{\circ} \mathrm{C}$ immediately after collection. Information on medical history, ACR criteria for SLE, and current disease activity was registered into a database, which included no personal identifiers. Laboratory data included blood cell counts, routine chemistry, urinalysis, complement levels, anti-dsDNA, anti-Sm, anti-RNP, anticardiolipin (ACA) IgG and IgM, lupus anticoagulant (LAC), anti- $\beta 2$ glycoprotein I, anti-Ro, anti-La, and antiprotein $\mathrm{S}$ antibody. $\mathrm{C} 3$ and $\mathrm{C} 4$ were measured in the Oklahoma Medical Research Foundation clinical laboratory by standard nephelometric techniques. Disease activity was scored using the Systemic Lupus Erythematosus Disease Activity Index (SLEDAI) and the British Isles Lupus Assessment Group (BILAG) Instrument [26,27].

Prior to participation, all subjects gave informed consent to donate their blood samples and de-identified clinical information for research, and the study was approved by the Institutional Review Boards of Oklahoma Medical Research Foundation and of Temple University.

\section{Measurement of plasma Gas 6 concentrations}

Gas6 was measured with a sandwich ELISA modified from a previously developed and validated protocol [28]. Briefly, 96-well plates were coated overnight with antiGas6 capture antibody (goat polyclonal affinity purified IgG, R\&D Systems, Minneapolis, MI, USA). The antigen was detected by a secondary biotin-conjugated antibody (Biotinylated anti-human Gas6 antibody, R\&D Systems, Minneapolis, MI, USA), and a streptavidin-peroxidase conjugate (R\&D Systems, Minneapolis, MI, USA) and TMB (3,3',5,5'-tetramethylbenzidine, R\&D Systems, Minneapolis, MI, USA). The reaction was stopped with $2 \mathrm{~N}$ sulphuric acid and absorbance detected at $450 \mathrm{~nm}$. The absorbance at $450 \mathrm{~nm}$ was read with a reference wavelength set at $570 \mathrm{~nm}$ using a Versamax microplate reader (Molecular Devices, Sunnyvale, CA, USA). The optical density (OD) for each point was determined from the average of duplicate samples. Gas6 concentrations were determined using Softmax software (Molecular Devices, Sunnyvale, CA, USA) by applying a fourparameter logistic regression to the calibration curve prepared from duplicate serial dilutions of purified Gas6 protein (R\&D Systems, Minneapolis, MI, USA). The 


\begin{tabular}{|c|c|c|c|}
\hline & $\begin{array}{l}\text { Lupus matched } \\
\quad(n=45)\end{array}$ & $\begin{array}{l}\text { Normal control } \\
(n=45)\end{array}$ & $\begin{array}{l}\text { Lupus unmatched } \\
(n=62)\end{array}$ \\
\hline Age (years) & $40.47 \pm 15.5$ & $41.38 \pm 15.9$ & $37.27 \pm 13.02$ \\
\hline $\operatorname{Sex}(F: M)$ & $34: 11$ & $34: 11$ & $51: 11$ \\
\hline \multicolumn{4}{|l|}{ Ethnicity } \\
\hline Caucasian & 41 & 41 & 54 \\
\hline African & 2 & 2 & 2 \\
\hline Asian & 1 & 1 & 3 \\
\hline American Indian & 1 & 1 & 3 \\
\hline ACR total & $5.51 \pm 1.69$ & & $5.53 \pm 1.72$ \\
\hline Anti-dsDNA Ab (\%) & 33.3 & & 22.6 \\
\hline Anti-Sm Ab (\%) & 28.9 & & 12.5 \\
\hline Anti-Ro (SSA) Ab (\%) & 42.2 & & 35.5 \\
\hline Anti-La (SSB) Ab (\%) & 8.9 & & 22.6 \\
\hline Anticardiolipin Ab (\%) & 48.8 & & 35.7 \\
\hline Lupus anticoagulant (\%) & 15.6 & & 11.7 \\
\hline Anti-B2 glycoprotein Ab (\%) & 11.1 & & 14.5 \\
\hline APS (\%) & 37.8 & & 14.8 \\
\hline Decreased C3 (\%) & 8.9 & & 4.8 \\
\hline Decreased C4 (\%) & 42.2 & & 30.7 \\
\hline SLEDAI & $6.02 \pm 4.3$ & & $4.75 \pm 4.08$ \\
\hline BILAG & $6.93 \pm 5.34$ & & $5.59 \pm 3.73$ \\
\hline
\end{tabular}

$\mathrm{Ab}$, antibody; ACR total, the number of American College of Rheumatology 1982 revised criteria for classification of systemic lupus erythematosus; APS, antiphospholipid syndrome; BILAG, British Isles Lupus Assessment Group; F, female; M, male; SLEDAI, Systemic Lupus Erythematosus Disease Activity Index.

intra-assay and inter-assay coefficient of variation (CV) were $4.52 \%$ and $11.8 \%$, respectively.

\section{Measurement of plasma free protein $\mathrm{S}$ concentrations}

Free protein $\mathrm{S}$ levels were quantified using the free protein S ELISA kit (Diagnostica Stago, Parsippanny, NJ, USA) according to the manufacturer's instructions. The ELISA utilizes two monoclonal antibodies, each specific for free protein $S$ epitopes [29]. Briefly, heparinized plasma samples were diluted 1:20 in 1\% BSA and duplicate $200 \mu \mathrm{l}$ samples applied to the precoated 96-well plate. Serial dilutions of purified protein S (Hematologic Technologies Inc., Essex Junction, VT, USA) starting at $20 \mu \mathrm{g} / \mathrm{ml}$ were used to construct a standard curve. These were further diluted 1:20 (in 1\% BSA) before being applied to the plate in duplicate. Four blank wells received $200 \mu \mathrm{l} 1 \% \mathrm{BSA}$. The horseradish peroxidase (HRP)-conjugated secondary antibody (50 $\mu \mathrm{l} /$ well) was added immediately. The plate was developed with 200 $\mu \mathrm{l} /$ well of TMB substrate for five minutes as described for the Gas6 ELISA. The intra-assay and inter-assay CVs were $6.1 \%$ and $13.5 \%$, respectively.

\section{Statistical analysis}

The data were expressed as mean \pm standard deviation (SD). An unpaired Student's $t$-test was used for statistical comparison of plasma Gas6 and protein S levels between matched $45 \mathrm{SLE}$ patients and $45 \mathrm{NC}$ and of those according to the clinical manifestations in total 107 patients with SLE. When the data did not show Gaussian distribution, the Mann-Whitney U-test was used. To detect correlation between continuous data, the Pearson correlation coefficient was applied. Prizm software (GraphPad Software, La Jolla, CA, USA) was employed for all analyses. For all tests, a $P$ value of less than 0.05 was regarded as significant.

\section{Results}

Gas6 and free protein S concentration in SLE and NC

The plasma concentrations of Gas 6 were almost identical between 45 SLE patients and age, gender and ethnicity matched $45 \mathrm{NC}(15.55 \pm 4.39$ vs. $15.89 \pm 6.88 \mathrm{ng} /$ $\mathrm{mL}$, respectively; Figure 1a). Also, there was no difference in the level of free protein $S$ between them (6.44 \pm 1.75 vs. $6.91 \pm 1.74 \mu \mathrm{g} / \mathrm{mL}$, respectively; Figure $1 \mathrm{~b})$. In examining the levels of free protein $\mathrm{S}$ in all 107 SLE patients, free protein $\mathrm{S}$ was positively correlated with age $(\mathrm{r}=0.2405, P=0.0126)$, but Gas6 levels did not increase with age (Figure 2). The concentrations of Gas6 and free protein $\mathrm{S}$ were slightly higher in females than in males, but the difference was not significant.

As Gas6 and protein S are closely related, and both can function as intermediaries for TAM receptor kinase binding to apoptotic cells, we evaluated whether their levels would be related to each other; however, there was no correlation between the concentrations of Gas6 


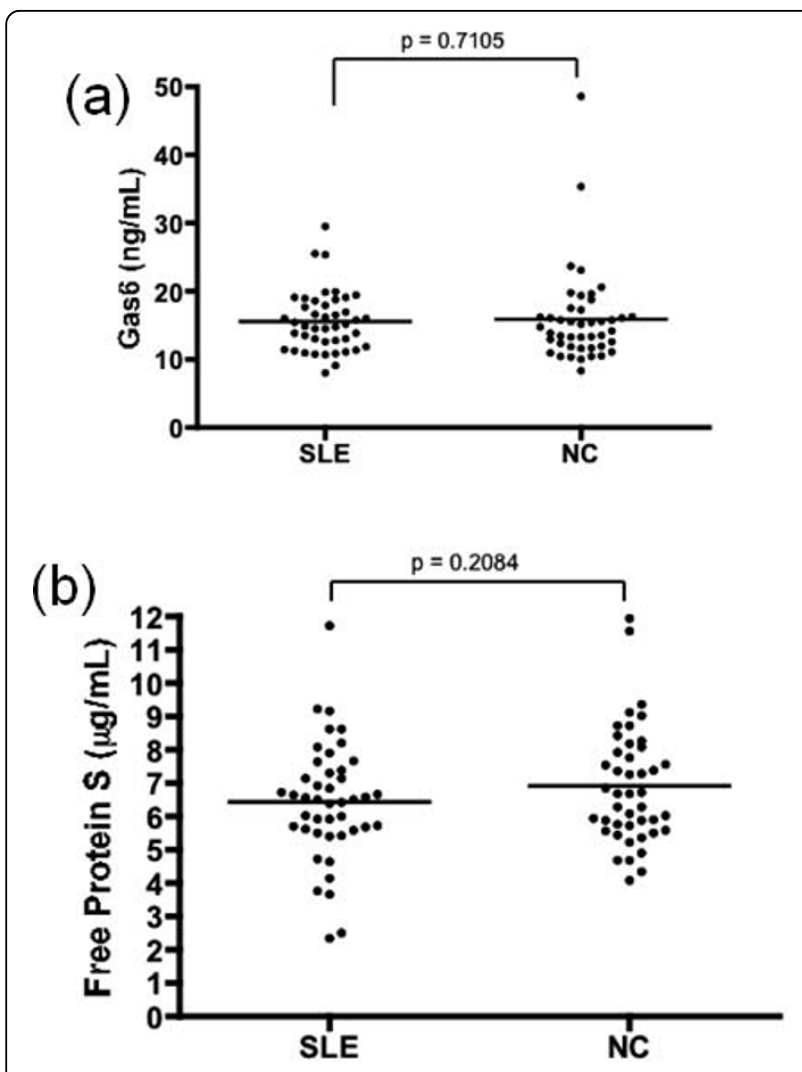

Figure 1 Plasma levels of (a) Gas6 and (b) free protein $S$ in age, gender and ethnicity matched SLE and NC. NC, normal controls; SLE, systemic lupus erythematosus.

and free protein S in SLE patient plasma (data not shown).

\section{Clinical characteristics and Gas6 and free protein S in SLE patients}

The concentrations of free protein $\mathrm{S}$ were significantly lower in SLE patients with a history of serositis, neurologic disorder, hematologic disorder, and immunologic disorder (defined by meeting 1982 revised ACR criteria than in those patients without these SLE features (Figure 3 ). In the patients with antiphospholipid syndrome (APS), free protein $\mathrm{S}$ levels were not different from patients without a history of APS. Also, free protein $S$ in patients known to have a history of pathologic thrombosis (with or without meeting autoantibody requirements for APS) did not differ from those without thrombotic history. There was no difference in the levels of Gas6 in any subset of patients excepting neurologic disorder. Although the number of patients with a history of neurologic disorder was only five, they had elevated Gas6 levels compared with patients without a history of neurologic disorder (Figure 3e).

Free protein $\mathrm{S}$ was slightly lower in the patients with anti-dsDNA than those without, but the difference was

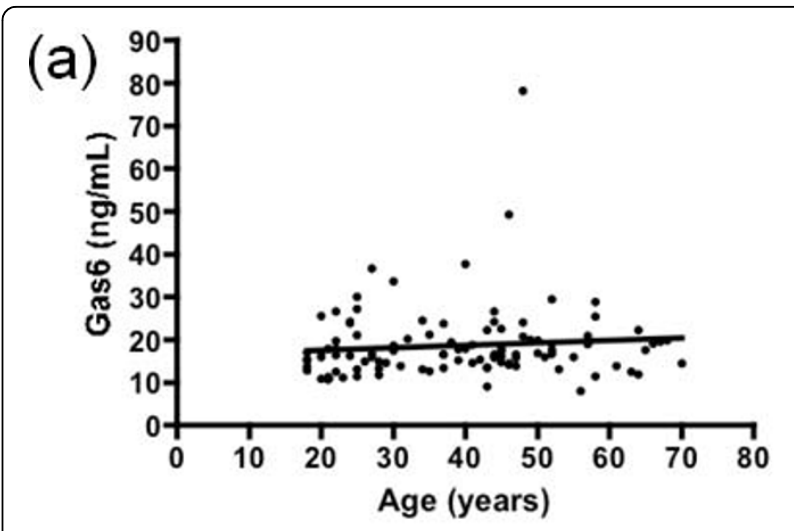

(b)

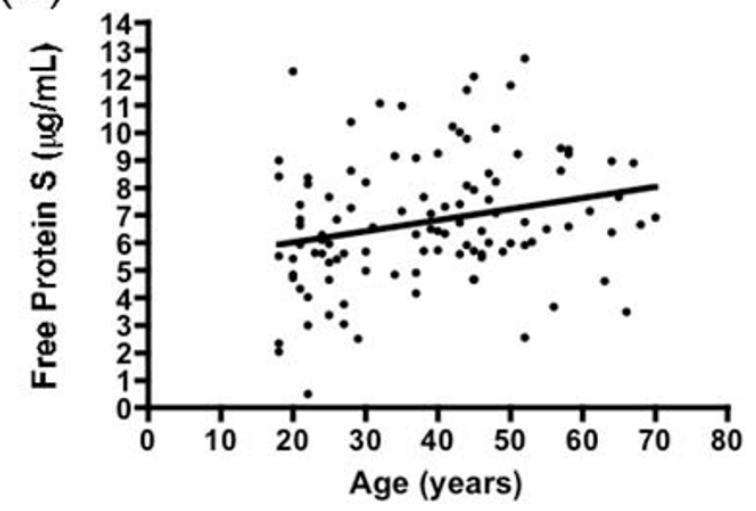

Figure 2 Plasma concentrations of (a) Gas6 and (b) free protein $S$ in SLE patients according to age. SLE, systemic lupus erythematosus.

not significant. The SLE patients with anti-Sm showed lower free protein $\mathrm{S}$ levels than those without (Figure 4a).

There are conflicting reports about free protein $\mathrm{S}$ levels in the patients with antiphospholipid antibody [22,23,30-33]. Our study found concentrations of free protein $S$ to be lower in the patients with ACA (Figure $4 b)$. However, there were no differences in the levels of free protein $S$ between patients with and without LAC and anti- $\beta 2$ glycoprotein I, respectively.

Among five SLE patients with anti-protein S antibodies, four had a history of thrombosis and three patients were positive for ACA; however, their acute levels of free protein $\mathrm{S}$ were not different from the patients without anti-protein $S$ antibodies (data not shown).

Protein S levels correlate with C3 and C4 in SLE patients The concentrations of free protein $\mathrm{S}$ were lower in patients with decreased C3 or C4, markers commonly used in assessing disease activity. It was striking that 


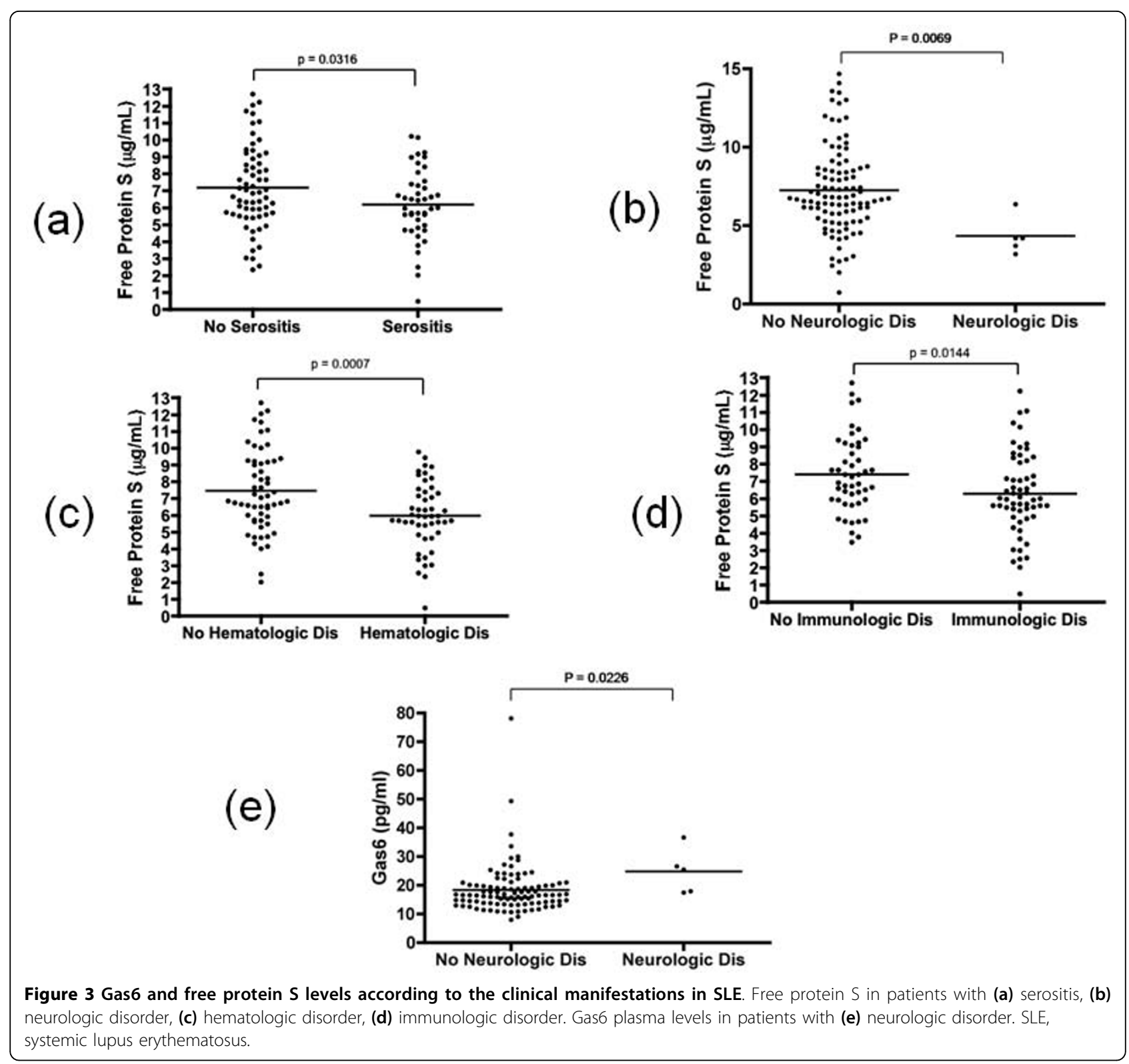

free protein $\mathrm{S}$ was positively correlated with $\mathrm{C} 3$ $(\mathrm{r}=0.3858, P<0.0001$; Figure $5 \mathrm{a})$ and $\mathrm{C} 4(\mathrm{r}=0.4275$, $P<0.0001$; Figure $5 \mathrm{~b})$.

\section{Disease activity and Gas6 and protein S in SLE patients}

We assessed overall disease activity with SLEDAI and BILAG composite scores, but did not find any correlation in a cross-sectional population comparison with levels of Gas6 or free protein S.

In the subset of patients with active BILAG hematologic involvement, whose BILAG score is not zero, the levels of Gas6 were higher $(23.05 \pm 24.88$ vs $16.99 \pm$ $6.93 \mathrm{ng} / \mathrm{mL}, P=0.008$; Figure $5 \mathrm{c}$ ) and those of free protein $\mathrm{S}$ were lower $(6.14 \pm 0.46$ vs $7.16 \pm 2.37 \mu \mathrm{g} / \mathrm{mL}$,
$P=0.036$; Figure $5 \mathrm{~d}$ ) compared with patients without BILAG hematologic involvement. In addition, the patients with a BILAG score greater than or equal to three showed further increased concentration of Gas6 $(29.93 \pm 24.88 \mathrm{ng} / \mathrm{ml})$ and those of free protein $\mathrm{S}(5.57$ $\pm 0.46 \mu \mathrm{g} / \mathrm{mL})$.

\section{Discussion}

Abnormal clearance of apoptotic cells may be important in the development of autoantibodies in SLE. As the TAM kinases may be important in the disposition of apoptotic cells, we evaluated plasma concentrations of their ligands Gas6 and free protein S. Although the levels of Gas6 and free protein S were not different 


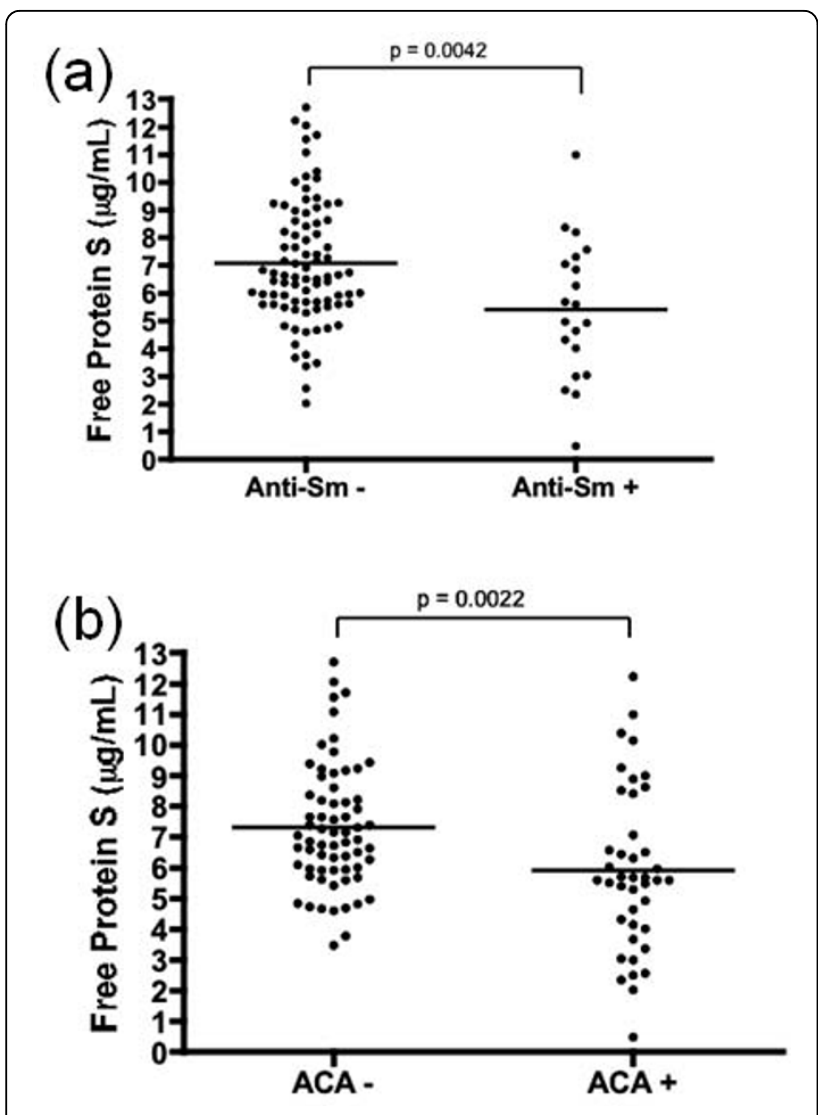

Figure 4 Levels of free protein S according to the presence of autoantibodies in SLE. Free protein S in patients with (a) anti-Sm and (b) anticardiolipin (ACA). SLE, systemic lupus erythematosus.

overall between patients with SLE and matched healthy controls, free protein $S$ was decreased in subsets of SLE patients with a history of serositis, neurologic, hematologic, and immunologic disorder. It was especially noteworthy that the concentrations of free protein $\mathrm{S}$ were correlated with C3 and C4. Protein S was decreased in SLE patients with active hematologic disease as defined by the BILAG index. In contrast to the findings for protein S, reduced levels of Gas6 were not associated with more active disease, with the possible exception of neurologic disorder, although this analysis was limited by a small number of patients. Surprisingly, active hematologic disease as defined by BILAG revealed an unexpected association with elevated, not reduced Gas6 levels.

Protein S is a vitamin K-dependent plasma anticoagulant protein and its deficiency leads to hypercoagulability syndromes with increased risk for venous thrombosis. However, there have been limited reports about functional effects of protein $\mathrm{S}$ independent of its anticoagulant function. After identification of TAM kinases as receptors for protein $\mathrm{S}$, this protein was shown to be required for the efficient uptake of apoptotic cells by macrophages in vitro [34], suggesting an important role in immune clearance. Protein S may play a particularly significant role in the removal of apoptotic cells because of its high plasma concentration, despite its apparent lower affinity for the receptor than Gas6. In the study of c-mer-mediated phagocytosis of apoptotic cells, protein $\mathrm{S}$ stimulated phagocytosis as well as or better than Gas6 [35,36]. Therefore, it is possible that insufficient levels of protein S may lead to inefficient clearance of apoptotic cells, resulting in exposure of cellular contents to immune cells and promoting an autoimmune response.

Several reports have suggested that the levels of free protein S may be lower in patients with SLE $[22,23,32]$. In the present study, there was no significant difference overall in circulating free protein $S$ between patients with SLE and matched healthy controls. However, the concentrations of free protein $S$ did appear to be decreased in subsets of those patients with a history of certain clinical manifestations, and low protein S correlated with acute evidence of hematologic disease activity and complement consumption. These findings support the possibility of a novel functional link between the coagulation system and distinct inflammatory responses in SLE. It is well known that there is increased cardiovascular mortality and morbidity among SLE patients, which is not fully explained by traditional risk factors $[37,38]$. Our results raise the possibility that, in a definable subset of patients with SLE, disease activity may lead to a decrease in the level of free protein $S$, which then may increase thrombogenicity. It should be considered that the protein that regulates levels of free protein $\mathrm{S}$ is the C4b-binding protein, which is a critical complement regulator as well [39]. The failure in our series to find decreased levels of protein $S$ in patients with previous thrombosis could reflect the very small number of patients in that category, along with the multiple risk factors that are probably involved in the pathologic hypercoagulability of SLE. Additionally, this was a crosssectional analysis, whereas at least one report has suggested that decreased free protein $\mathrm{S}$ may be more likely to be observed closer in time to a thrombotic event in patients with SLE [40]. Although decreased protein S levels may be secondary to SLE activity, we favor the hypothesis that a decrease in protein $S$ may actually contribute to SLE pathogenesis, as discussed above and suggested by Rothlin and colleagues [41].

Previous reports have observed an association between reduced levels of free protein $S$ and antiphospholipid antibody in SLE $[23,30]$. It has been suggested that acquired protein $\mathrm{S}$ deficiency could contribute to increased risk of thrombosis in patients with antiphospholipid antibody. However, other investigations have not confirmed an association [22,31-33]. These reports 
(a)

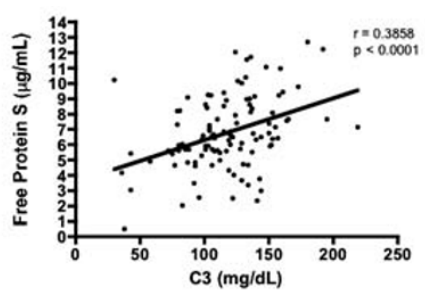

(c)

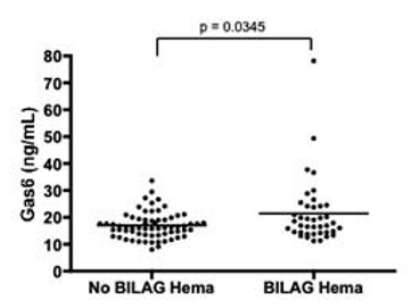

(b)

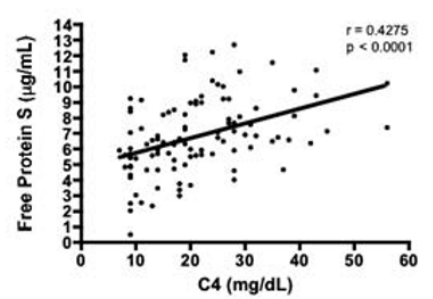

(d)

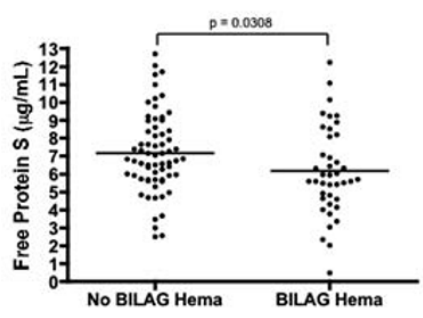

Figure 5 Gas6 and free protein S levels and disease activity. Correlation between free protein S and (a) C3 or (b) C4. (c) Gas 6 and (d) free protein $\mathrm{S}$ levels in patients with BILAG hematology. BILAG, British Isles Lupus Assessment Group.

evaluated free protein $\mathrm{S}$ in a relatively small number of SLE patients (30 to 50 patients). In the present study assessing 107 SLE patients, free protein S levels were significantly lower only in those patients with ACA, but not in those with LAC and anti- $\beta 2$ glycoprotein I. Autoantibodies directed against protein $\mathrm{S}$ have been associated with thrombosis in patients with APS and SLE $[32,42-44]$. However, the presence of anti-protein S antibodies in patients have not been found to reduce the concentrations of free protein S [32,42]. Our findings were consistent with these results although the prevalence of anti-protein $\mathrm{S}$ was lower in our patients $(5 \%)$ than previous reports (26 to $31 \%$ ).

Gas6 is a cell survival, proliferation and chemotactic factor and also a recognition bridge between phagocytes and apoptotic cells. Gas6 is present at a low concentration in plasma; however, it can be released by endothelial cells and leukocytes during serum starvation or under inflammatory conditions $[19,21,45-47]$. The receptors that bind Gas6 (Tyro3, Axl, and c-mer) have an immunoregulatory role, modulating macrophage activation following an initial immune stimulus $[9,48]$. Gas6 may thus be supposed to participate in inflammation by interfering with macrophage-lymphocyte crosstalk. Furthermore, Gas6 might be involved in other chronic systemic autoimmune diseases, such as rheumatoid arthritis and chronic inflammatory demyelinating polyneuropathy $[49,50]$. It has been suggested that Gas6 is involved in macrophage activation in chronic autoimmunity as an autocrine or paracrine regulatory molecule for monocytes [51].

In the present study, plasma Gas6 levels in patients with SLE were the same as in matched HC and levels were unrelated to age and gender. The concentration of Gas6 was increased in the patients with a history of neurologic disorder and acute activity in the BILAG hematology system. The latter results may reflect the inducible nature of Gas6. Basal levels of Gas6 were low, yet it is known to be upregulated in certain states of intense inflammation such as septic shock and severe acute pancreatitis [19-21]. A recent report finding that almost all Gas6 present in healthy subjects is bound by soluble Axl may explain why there is actually little free Gas6 present in either normal or SLE serum, although the extent to which our ELISA can detect axl-bound Gas6 has not been tested [52].

In SLE, free protein $S$ was decreased in patients characterized by a history of serositis, neurologic, hematologic, and immunologic disorder. Protein $\mathrm{S}$ was also decreased in patients with low $\mathrm{C} 3$ and $\mathrm{C} 4$ and active hematologic activity. Thus, free protein $\mathrm{S}$ may be useful as a biomarker of clinical phenotype and disease activity.

Furthermore, the decrease of protein $S$ and increase of Gas6 in patients with acute activity in the BILAG hematologic system suggests the possibility of a unique link between inflammation and thrombotic risk that could be explored mechanistically.

\section{Conclusions}

The TAM ligands are important apoptotic debris receptors and regulators of innate immunity. Our study shows that low levels of one TAM ligand, protein $\mathrm{S}$, correlate with $\mathrm{C} 3$ and $\mathrm{C} 4$ levels and with clinical manifestations of SLE. In contrast, circulating levels of Gas6, the other principal TAM ligand, have little apparent 
relation to SLE laboratory or clinical manifestations. These data support the view that ligation of the TAM ligands through protein S but not Gas6 is important in clearance of debris and regulation of the innate immune system in patients with SLE.

\begin{abstract}
Abbreviations
ACA: anticardiolipin; ACR: American College of Rheumatology; APS: antiphospholipid syndrome; BILAG: British Isles Lupus Assessment Group Instrument; BSA: bovine serum albumin; CV: coefficient of variation; ELISA enzyme linked immunosorbent assay; Gas6: growth arrest-specific 6; HRP: horseradish peroxidase; Ig: immunoglobulin; NC: normal controls; SLE: systemic lupus erythematosus; SLEDAI: systemic lupus erythematosus disease activity index; TAM kinases: tyro 3, axl, mer.
\end{abstract}

\section{Acknowledgements}

This research was supported by a grant from NIAID (Autoimmunity Centers of Excellence 1 U19AI082726). We thank Dr. Robert Roubey (University of North Carolina) for helpful discussions, Dr. Gwyn Cutsforth (Diagnostica Stago) for generously supplying protein $\mathbf{S}$ assay kits, and Dr. John Gaughan (Temple University) for help with biostatistics.

\section{Author details}

'Section of Rheumatology, Department of Medicine, Temple University School of Medicine, 3322 North Broad Street, Room 205, Philadelphia, PA 19140, USA. ²Department of Allergy-Rheumatology, Ajou University School of Medicine, Woncheon-dong San 5, Youngtong-gu, Suwon 443-721, Korea. ${ }^{3}$ Clinical Pharmacology Research Program, Oklahoma Medical Research Foundation, 825 N.W. 13th Street, Oklahoma City, OK 73106, USA.

\section{Authors' contributions}

CHS designed and executed experiments, interpreted data, and wrote the manuscript. BH performed experiments and interpreted data. SL performed pilot experiments and interpreted data. JTM supplied samples and clinical data, interpreted results, and edited the manuscript. PLC designed experiments, interpreted data, and edited the manuscript.

\section{Competing interests}

The authors declare that they have no competing interests.

Received: 6 May 2010 Revised: 1 July 2010 Accepted: 16 July 2010 Published: 16 July 2010

\section{References}

1. D'Cruz DP, Khamashta MA, Hughes GR: Systemic lupus erythematosus. Lancet 2007, 369:587-596.

2. Rahman A, Isenberg DA: Systemic lupus erythematosus. N Engl J Med 2008, 358:929-939.

3. Casciola-Rosen LA, Anhalt G, Rosen A: Autoantigens targeted in systemic lupus erythematosus are clustered in two populations of surface structures on apoptotic keratinocytes. J Exp Med 1994, 179:1317-1330.

4. Herrmann M, Voll RE, Zoller OM, Hagenhofer M, Ponner BB, Kalden JR: Impaired phagocytosis of apoptotic cell material by monocyte-derived macrophages from patients with systemic lupus erythematosus. Arthritis Rheum 1998, 41:1241-1250.

5. Munoz LE, van Bavel C, Franz S, Berden J, Herrmann M, van der Vlag J: Apoptosis in the pathogenesis of systemic lupus erythematosus. Lupus 2008, 17:371-375.

6. Cohen PL: Apoptotic cell death and lupus. Springer Semin Immunopathol 2006, 28:145-152.

7. Cohen PL, Caricchio R: Genetic models for the clearance of apoptotic cells. Rheum Dis Clin North Am 2004, 30:473-486, viii.

8. Scott RS, McMahon EJ, Pop SM, Reap EA, Caricchio R, Cohen PL, Earp HS, Matsushima GK: Phagocytosis and clearance of apoptotic cells is mediated by MER. Nature 2001, 411:207-211.

9. Lemke G, Rothlin CV: Immunobiology of the TAM receptors. Nat ReV Immunol 2008, 8:327-336.
10. Cohen PL, Caricchio R, Abraham V, Camenisch TD, Jennette JC, Roubey RA, Earp HS, Matsushima G, Reap EA: Delayed apoptotic cell clearance and lupus-like autoimmunity in mice lacking the c-mer membrane tyrosine kinase. J Exp Med 2002, 196:135-140.

11. Chen J, Carey K, Godowski PJ: Identification of Gas6 as a ligand for Mer, a neural cell adhesion molecule related receptor tyrosine kinase implicated in cellular transformation. Oncogene 1997, 14:2033-2039.

12. Shao WH, Zhen $Y$, Eisenberg RA, Cohen PL: The Mer receptor tyrosine kinase is expressed on discrete macrophage subpopulations and mainly uses Gas6 as its ligand for uptake of apoptotic cells. Clin Immunol 2009, 133:138-144.

13. Stitt TN, Conn G, Gore M, Lai C, Bruno J, Radziejewski C, Mattsson K, Fisher J, Gies DR, Jones PF, et al: The anticoagulation factor protein $S$ and its relative, Gas6, are ligands for the Tyro 3/Axl family of receptor tyrosine kinases. Cell 1995, 80:661-670.

14. Uehara $\mathrm{H}$, Shacter E: Auto-oxidation and oligomerization of protein $\mathrm{S}$ on the apoptotic cell surface is required for Mer tyrosine kinase-mediated phagocytosis of apoptotic cells. J Immunol 2008, 180:2522-2530.

15. Manfioletti G, Brancolini C, Avanzi G, Schneider C: The protein encoded by a growth arrest-specific gene (gas6) is a new member of the vitamin Kdependent proteins related to protein $\mathrm{S}$, a negative coregulator in the blood coagulation cascade. Mol Cell Biol 1993, 13:4976-4985.

16. Fernandez-Fernandez L, Bellido-Martin L, Garcia de Frutos P: Growth arrestspecific gene 6 (GAS6). An outline of its role in haemostasis and inflammation. Thromb Haemost 2008, 100:604-610.

17. Hafizi S, Dahlback B: Gas6 and protein S. Vitamin K-dependent ligands for the Axl receptor tyrosine kinase subfamily. FEBS J 2006, 273:5231-5244.

18. Dahlback B: The tale of protein $\mathrm{S}$ and $\mathrm{C} 4 \mathrm{~b}$-binding protein, a story of affection. Thromb Haemost 2007, 98:90-96.

19. Uehara S, Handa H, Gotoh K, Tomita H, Sennshuu M: Plasma concentrations of growth arrest-specific protein 6 and protein $S$ in patients with acute pancreatitis. J Gastroenterol Hepatol 2009, 24:1567-1573.

20. Borgel D: Gas6 inflames cell interactions. Blood 2008, 111:3915.

21. Gibot S, Massin F, Cravoisy A, Dupays R, Barraud D, Nace L, Bollaert PE: Growth arrest-specific protein 6 plasma concentrations during septic shock. Crit Care 2007, 11:R8.

22. Keeling DM, Campbell SJ, Mackie IJ, Machin SJ, Isenberg DA: Total and free protein S in systemic lupus erythematosus. Thromb Res 1990, 60:237-240.

23. Ginsberg JS, Demers C, Brill-Edwards P, Bona R, Johnston M, Wong A, Denburg JA: Acquired free protein $S$ deficiency is associated with antiphospholipid antibodies and increased thrombin generation in patients with systemic lupus erythematosus. Am J Med 1995, 98:379-383.

24. Brouwer $J$, Bijl M, Veeger NJ, Kluin-Nelemans HC, van der Meer J: The contribution of inherited and acquired thrombophilic defects, alone or combined with antiphospholipid antibodies, to venous and arterial thromboembolism in patients with systemic lupus erythematosus. Blood 2004, 104:143-148.

25. Tan EM, Cohen AS, Fries JF, Masi AT, McShane DJ, Rothfield NF, Schaller JG, Talal N, Winchester RJ: The 1982 revised criteria for the classification of systemic lupus erythematosus. Arthritis Rheum 1982, 25:1271-1277.

26. Bombardier C, Gladman DD, Urowitz MB, Caron D, Chang CH: Derivation of the SLEDAI. A disease activity index for lupus patients. The Committee on Prognosis Studies in SLE. Arthritis Rheum 1992, 35:630-640.

27. Yee CS, Farewell V, Isenberg DA, Prabu A, Sokoll K, Teh LS, Rahman A, Bruce IN, Griffiths B, Akil M, McHugh N, D'Cruz D, Khamashta MA, Bowman S, Maddison P, Zoma A, Allen E, Gordon C: Revised British Isles Lupus Assessment Group 2004 index: a reliable tool for assessment of systemic lupus erythematosus activity. Arthritis Rheum 2006, 54:3300-3305.

28. Alciato F, Sainaghi PP, Castello L, Bergamasco L, Carnieletto S, Avanzi GC: Development and validation of an ELISA method for detection of growth arrest specific 6 (GAS6) protein in human plasma. J Immunoassay Immunochem 2008, 29:167-180.

29. Aillaud MF, Pouymayou K, Brunet D, Parrot G, Alessi MC, Amiral J, JuhanVague I: New direct assay of free protein $S$ angien applied to diagnosis of protein S deficiency. Thromb Haemost 1996, 75:283-285.

30. Tomas JF, Alberca I, Tabernero MD, Cordero M, Del Pino-Montes J, Vicente $V$ : Natural anticoagulant proteins and antiphospholipid antibodies in systemic lupus erythematosus. J Rheumatol 1998, 25:57-62.

31. Matsuda J, Gohchi K, Gotoh M, Tsukamoto M, Saitoh N: Plasma concentrations of total/free and functional protein $\mathrm{S}$ are not decreased 
in systemic lupus erythematosus patients with lupus anticoagulant and/ or antiphospholipid antibodies. Ann Hematol 1994, 69:311-315.

32. Song KS, Park YS, Kim HK: Prevalence of anti-protein S antibodies in patients with systemic lupus erythematosus. Arthritis Rheum 2000, 43:557-560.

33. Afeltra A, Vadacca M, Conti L, Galluzzo S, Mitterhofer AP, Ferri GM, Del Porto F, Caccavo D, Gandolfo GM, Amoroso A: Thrombosis in systemic lupus erythematosus: congenital and acquired risk factors. Arthritis Rheum 2005, 53:452-459.

34. Anderson HA, Maylock CA, Williams JA, Paweletz CP, Shu H, Shacter E: Serum-derived protein $\mathrm{S}$ binds to phosphatidylserine and stimulates the phagocytosis of apoptotic cells. Nat Immunol 2003, 4:87-91.

35. Hall MO, Obin MS, Heeb MJ, Burgess BL, Abrams TA: Both protein $S$ and Gas6 stimulate outer segment phagocytosis by cultured rat retinal pigment epithelial cells. Experimental Eye Research 2005, 81:581-591.

36. Wu Y, Singh S, Georgescu MM, Birge RB: A role for Mer tyrosine kinase in alphavbeta5 integrin-mediated phagocytosis of apoptotic cells. J Cell Sci 2005, 118:539-553.

37. Manzi S, Meilahn EN, Rairie JE, Conte CG, Medsger TA Jr, JansenMcWilliams L, D'Agostino RB, Kuller LH: Age-specific incidence rates of myocardial infarction and angina in women with systemic lupus erythematosus: comparison with the Framingham Study. Am J Epidemiol 1997, 145:408-415.

38. Roman MJ, Shanker BA, Davis A, Lockshin MD, Sammaritano L, Simantov R, Crow MK, Schwartz JE, Paget SA, Devereux RB, Salmon JE: Prevalence and correlates of accelerated atherosclerosis in systemic lupus erythematosus. N Engl J Med 2003, 349:2399-2406.

39. Dahlback B: Interaction between complement component C4b-binding protein and the vitamin K-dependent protein S. A link between blood coagulation and the complement system. Scand I Clin Lab Invest Suppl 1985, 177:33-41.

40. Ruiz-Arguelles GJ, Ruiz-Arguelles A, Alarcon-Segovia D, Drenkard C, Villa A, Cabiedes J, Presno-Bernal M, Deleze M, Ortiz-Lopez R, Vazquez-Prado J: Natural anticoagulants in systemic lupus erythematosus. Deficiency of protein $\mathrm{S}$ bound to C4bp associates with recent history of venous thromboses, antiphospholipid antibodies, and the antiphospholipid syndrome. J Rheumatol 1991, 18:552-558.

41. Rothlin CV, Ghosh S, Zuniga El, Oldstone MD, Lemke G: TAM receptors are pleiotropic inhibitors of the immune response. Cell 2007, 131:1124-1136.

42. Bertolaccini ML, Sanna G, Ralhan S, Gennari LC, Merrill JT, Khamashta MA, Hughes GR: Antibodies directed to protein $S$ in patients with systemic lupus erythematosus: prevalence and clinical significance. Thromb Haemost 2003, 90:636-641.

43. Oosting JD, Derksen RH, Bobbink IW, Hackeng TM, Bouma BN, de Groot PG: Antiphospholipid antibodies directed against a combination of phospholipids with prothrombin, protein C, or protein S: an explanation for their pathogenic mechanism? Blood 1993, 81:2618-2625.

44. Nojima J, Kuratsune H, Suehisa E, Futsukaichi $Y$, Yamanishi H, Machii T, Iwatani $Y$, Kanakura $Y$ : Association between the prevalence of antibodies to beta(2)-glycoprotein I, prothrombin, protein C, protein S, and annexin $V$ in patients with systemic lupus erythematosus and thrombotic and thrombocytopenic complications. Clin Chem 2001, 47:1008-1015.

45. Borgel D, Clauser S, Bornstain C, Bieche I, Bissery A, Remones V, Fagon JY, Aiach M, Diehl JL: Elevated growth-arrest-specific protein 6 plasma levels in patients with severe sepsis. Crit Care Med 2006, 34:219-222.

46. Yin JL, Pilmore HL, Yan YQ, McCaughan GW, Bishop GA, Hambly BD, Eris JM: Expression of growth arrest-specific gene 6 and its receptors in a rat model of chronic renal transplant rejection. Transplantation 2002, 73:657-660

47. Balogh I, Hafizi S, Stenhoff J, Hansson K, Dahlback B: Analysis of Gas6 in human platelets and plasma. Arterioscler Thromb Vasc Biol 2005, 25:1280-1286.

48. Lu Q, Lemke G: Homeostatic regulation of the immune system by receptor tyrosine kinases of the Tyro 3 family. Science 2001, 293:306-311.

49. O'Donnell K, Harkes IC, Dougherty L, Wicks IP: Expression of receptor tyrosine kinase Axl and its ligand Gas6 in rheumatoid arthritis: evidence for a novel endothelial cell survival pathway. Am J Pathol 1999. 154:1171-1180.

50. Sainaghi PP, Collimedaglia L, Alciato F, Leone MA, Puta E, Naldi P, Castello L, Monaco F, Avanzi GC: Elevation of Gas6 protein concentration in cerebrospinal fluid of patients with chronic inflammatory demyelinating polyneuropathy (CIDP). J Neurol Sci 2008, 269:138-142.

51. Lemke G, Lu Q: Macrophage regulation by Tyro 3 family receptors. Curr Opin Immunol 2003, 15:31-36.

52. Ekman C, Stenhoff J, Dahlback B: Gas6 is complexed to soluble tyrosine kinase receptor Axl in human blood. J Thromb Haemost 2010.

\section{doi:10.1186/ar3088}

Cite this article as: Suh et al: TAM receptor ligands in lupus: Protein S but not Gas6 levels reflect disease activity in systemic lupus erythematosus. Arthritis Research \& Therapy 2010 12:R146.

\section{Submit your next manuscript to BioMed Central and take full advantage of:}

- Convenient online submission

- Thorough peer review

- No space constraints or color figure charges

- Immediate publication on acceptance

- Inclusion in PubMed, CAS, Scopus and Google Scholar

- Research which is freely available for redistribution

Submit your manuscript at www.biomedcentral.com/submit
C Biomed Central 